Niko Pyrhönen, Karin Creutz and Marjukka Weide

\title{
8 Orchestrating National Unity: An Assessment of Discourses in Immigrant Legislation and the Surrounding Parliamentary and Public Debates
}

\subsection{Introduction}

In this paper, we examine the articulations and perceptions of the state's role in the management of immigration during the past decade in Finland. We look at recent developments in Finnish immigration legislation - with particular focus on the Aliens Act of 2004 - and in the surrounding debates in parliamentary and media arenas. With the focus on these debates, we seek to explicate in three separate sections how and to what effect the state's role is being articulated alongside the endeavours to manage immigration.

First, we consider the policy-level data in terms of the preparatory work in the ministries and in the parliamentary committees. This is done in order to identify some underlying national discourses that support the management of the perceivably immigration-induced, societal heterogenisation. Achieving this also entails identifying frames within which national belonging and unity are being discursively constructed vis-à-vis the immigrant Other. ${ }^{1}$ The section will also propose four frames through which national unity is discursively produced in the data considered in the subsequent sections. These frames will also be illustrated through some concrete examples from the preparatory process of the 2004 Aliens Act. By establishing this in the first section, this chapter outlines the nature and interconnectedness of the various impediments that the top-down articulations of national unity may present to the development of more decentralised and case-sensitive immigration regimes within a welfare state context.

Secondly, we examine the empirical manifestations of the belonging frames within parliamentary speeches of the Finnish MPs, analyzing the 2003-2004 debates on the Aliens Act and a complementary text from the 2003 Integration Act debates. We track down themes and ways of talking which relate to the ones identified in

1 Othering is an important theoretical apparatus here. It defines the process through which an individual or collective is placed in the position of the Other (Eide 2008:156). Simultaneously, the notion of a shared collective is delineated through these social boundaries. Thus, othering is decisive when discussing the questions of belonging that are in the core of national unity (McIver 2003). 
the preparatory material of the Aliens Act (section 1 of this paper). ${ }^{2}$ We regard the parliament as a privileged arena for making discursive constructions of national unity. Rather than really aiming at influencing the decisions, the plenary speeches address the citizens and the media, trying to communicate the angles and emphases of the representatives to those they claim to represent (see Saward 2006).

Thirdly, a similar kind of analysis is extended to the immigration debate in public fora in order to identify the kinds of articulations on the role of the state in the management of immigration that resonate there. This is crucial, because it is mainly through the media representations of state agency (rather than actual MP performances and the legislative process per se) through which the citizens participate in the public debate on immigration and hence also contribute to the delineation of the boundaries of national unity. The data considered here consists of editorials and newspaper articles, letters to the editor and posts to the discussion board of Finland's biggest newspaper Helsingin Sanomat. The accounts considered were published during the important junctions within the past decade when relevant immigrant legislation was pending (1999, 2004 and 2009).

In examining the discourses framing the state's role in the management of immigration, we adopt a markedly institutionalist (or top-down) perspective. This means that we are first and foremost concerned with what the state is perceived to be doing and what goals it is perceived to have in ministries, the parliament and in media debates. On this basis, in this paper we propose some effects these perceptions might have on civil society. This can be contrasted with many classical takes on the so called input model of representative democracy that start bottom-up, by tracing the development of policies from grass root ideas and public philosophies. ${ }^{3}$

Despite the above juxtaposition, we do acknowledge interplay between these two poles of civil society and government. We only start our analysis from the other end of the continuum. This means that we evaluate the role of the state and government as instruments of national unity by identifying characteristics in the top-down discourses that have been successfully mediated to penetrate into civil society. This entails examining those facets of popular articulations of national unity that belong in an officially sanctioned discourse in the sense of having a legalist and statist emphasis and dealing explicitly with the role of the state in the management, or orchestration, of immigration.

2 Here our assessment of the parliamentary debates is delimited by the framework established in the second section. For a grounded descriptive of the parliamentary debates on the Aliens Act of 2004, see Pellander, Saara. 2009. "Sending and Receiving, Welcoming and Excluding: Developments and Debates in Finland's Migration Policy.” Pp. 128-136 in Debating Migration: Political Discourse on Labor Immigration in Historical Perspective, edited by M. Spång and S. Mayer. Innsburg: Studien Verlag.

3 An example of the classic with the emphasis on the latter kind of bottom-up channeling would be Lipset, Seymour M. and Stein Rokkan, ed. 1967. Party Systems and Voter Alignments: Cross-National Perspectives. New York: Free Press, whereas our approach would share its starting point with historical institutionalist classics such as Huntington, Samuel. 1968. Political Order in Changing Societies. New Haven: Yale University Press. 
This approach is particularly interesting within the context of immigration, because at the same time that some contend that the role of the state and the national context are becoming less pertinent in the actual process of immigrant integration (Caponio and Borkert 2010), the articulations of how the state should manage the increase in the allegedly immigration-induced societal heterogeneity appear to be proliferating within the Finnish public debate. While we exemplify these articulations with only the Finnish context in mind, there is good reason to believe that the propagation of the statist critique of immigration within civil society is not a Finnish anomaly. Rather, this tendency could be hypothesised as a common feature of countries with a long welfare-state tradition and an enduring support for it even in the face of new serious macro-level challenges, as is particularly the case with the Nordic countries (Hemerijk 2004:184-185).

The relevance of the emphasis on the Finnish context can also be justified by regarding it as a 'case' where nation-minded articulations seek to challenge a supranational harmonisation of immigration related norms. The notion that national European regimes of immigration law are increasingly being constrained by the international discourse of human rights and free mobility - as stressed in treaties signed by most of the union countries - has become increasingly challenged (see, for example, Lahav 2004:26). This is also a further reason for not considering the Finnish public sphere here as an object of research per se, but rather as context, where many ubiquitously transnational juxtapositions are articulated.

Exploring the legislative dimension of immigration from ministry-level preparation through parliamentary performances to media discourses and public debates allows us to sketch a discursive continuum addressing the reinforcement of national unity from a top-down perspective. Especially for societies that are marked by relatively high levels of homogeneity in terms of ethnicity, the legislative process seeks to gather support from citizenry by reproducing many of the constructions of national unity that proliferate throughout civil society. However, to the extent that these legislative constructions are forged as tools for distinguishing existing, 'good' national' practices from those perceived as of foreign origin, the top-down dimension effectively reproduces ethnocentric particularisation in civil society instead of only passively reflecting some supposedly existing civic consensus. ${ }^{4}$ In terms of theoretical contributions, it is useful to consider the conclusions based on the Finnish data to give grounds for some tentative extrapolations concerning the nature of impediments that articulations of national unity may pose for the development of immigration and integration regimes and how some of these hurdles might be discursively overcome.

4 While there is, naturally, a significant pressure from the grass root level to influence public policy pertaining to immigration, our focus on representations of Finnishness exclusively in legislation-relevant discourse does not allow us to explore that avenue within the confines of this paper. 


\subsection{Framing the boundary-work of national unity - a model of discursive practices with reference to the preparatory process of the Aliens Act of 2004}

A multiplicity of societal practices and discourses incorporate the socio-spatial specifications of who is included and who is excluded (Paasi 2002:158) and, as such, these boundary-defining practices play a key role in the process of establishing and reproducing national unity. Configurations of these 'symbolic boundaries' have also been used to illustrate the sharpened public opinion toward immigration into European countries (see Bail 2008). Put simply, collective identification, solidarity and the sense of unity in the bonding sense of social capital (see Putnam 2000:2023) are negotiated in relation to these borders that also establish a more or less dichotomised relationship to an immigrant Other. We propose that a constructionist mindset in the analysis allows an acknowledgment of the top-down reproduction of national unity around the normalising institutional frames as one of the implicit co-products of this form of Othering, to which 'immigrants' (as a group purportedly forming a unitary whole) are subjected (concerning the use of reified categories in Othering, see, for example, Hall 1997). ${ }^{5}$

Here, a national immigration regime becomes crucial in the reproduction of national unity since such a regime incorporates an institutionalised, legal stance towards the Other. Moreover, such a national regime is not only manifest in the legislation but also reflects on the 'public philosophies' of the state's role in the integration of immigrants (see Favell 2001:14-16) as exemplified in part within the public debate on immigration legislation. Therefore, in order to study how national unity has been reproduced in Finland during the past decade, one important aspect to examine is how the articulations of the state's role in managing immigration contributes to this boundary-work by facilitating a national variant of unity as a counterpoise to the perceived immigrant-induced heterogeneity. This is also how these discourses can be linked to the practice of Othering in the Finnish context. ${ }^{6}$

There is another reason for concentrating on these discursively formed boundaries, as opposed to some quantitative immigration-relevant phenomena. Namely - as also suggested by our data - it is a relatively common perception among

5 It is relatively common in Finland to debate immigration with reference to the category of immigrants who, nevertheless, constitute a highly variable spectrum of people - refugees from Africa, migrant workers from Eastern Europe, skilled workers from US and wealthier European countries. It is questionable if they indeed do have some common denominator that is pertinent to many of the arguments made about 'immigrants'. This reification of represented categories is also criticized by Hall on a more theoretical level.

6 It is not possible to present a historical discussion of immigration and othering in Finland here. For good analysis on the process of othering towards immigrant minorities in Finland, see, for example, Löytty 2005. 
autochthonous populations who nurture narratives of an ethno-national homogeneity of the past to regard societal heterogenisation as significantly immigration-induced. These perceptions may spread even when asserting them may be clearly at odds with the demographic hard data on the magnitude of the impact of immigration. Indeed, often there are a myriad of other societal phenomena at work that may be much more efficient in eroding the traditional notion of the citizenry as homogenous (see, for example, Soysal 1994).

Such a development is particularly pertinent to Finland, which is also underlined by the fact that a markedly heated political and public debate has evolved over the phenomenon in the late 2000s (on the proliferation of anti-immigration sentiment in public debate and the 'I am not a racist, but...' discourse, see Keskinen 2009). This discursive development can be contrasted with the demographic fact by that, concurrently, the country has consistently experienced levels of immigration significantly below that of EU-15 countries. ${ }^{7}$

Indeed, we argue that within the Nordic welfare state context, nation-specific unity and solidarity constructions do play a major part in the way a 'just' and 'practicable' form of immigration management and integration is conceptualised. It seems that these relatively idiosyncratic considerations - rather than an application of some quantitative and objectively perceivable indicators - is what defines to a large degree how the policy programmes and other top-down measures for regulating immigration and organising immigrant integration are formulated by the government and evaluated by the citizens.

The discontinuity between perceptions and objective quantifiers pertaining to immigration is noticeable throughout assessed discourses. This suggests that although commonly framed otherwise by the discussants themselves - the material well-being of an ethnic Finn in Finland is not the explicit cause of anxiety in the discourses. Rather, the immigration-related anxiety concerns questions of identity that can be understood in terms of the third Lukesian level of power. According to Lukes, the first dimension of power is manifest in an explicit conflict of interest; for example, when one manner of redistribution is being chosen over others that are on the table. The second level pertains to the agenda setting power - the question of what issues are brought on the table in the first place. Finally, the most relevant dimension in the context of our study is the third dimension, which entails the power to change what people want by creating new kinds of identities (Lukes 1974:21-26).

7 United Nations, Department of Economic and Social Affairs, Population Division, "International Migration 2006" in United Nations Publication, No. E.06.XIII.6, March 2006. The discontinuity between the demographic reality and the public debate around immigration further suggests that the discursive construction of the phenomenon of immigration is highly dependent on nation-specific logic, rather than on search for some neoliberal rationalized optimal outcomes. 
It is from many perspectives useful to conceptualise Othering in terms of this third dimension of power, since the anxiety over national unity is rarely reducible either to the struggle for material resources or the ability of the 'power elite' to put immigrant issues on the political agenda. Rather, this third dimension of power, denoting the control over the subjectively experienced, identity-relevant interests, has great potential to explain the perceived need for top-down management of immigrant integration in terms of containment of increasing heterogenisation which is supposedly significantly eroding the national unity. As noted earlier, a more constructive, research-oriented approach allows us to see how the relative strength of the heterogenising impact of immigration vis-à-vis other, pre-existing processes of heterogenisation is highly questionable. The same applies for the empirical validity of the discourse linking national unity and the economic feasibility of welfare structures (Crepaz 2006). Therefore, with an emphasis on the discursive level, we have identified four discursive frames that produce national unity through Othering in the preparatory work of the Aliens Act of 2004. In the following we will first briefly introduce some interesting particularities of the Act. Then we will illustrate each of the aforementioned frames and their interconnectedness with concrete examples from the legislative context, before finally analysing the parliamentary and media debates by applying the same four-fold framework.

Starting in 2000, the Ministry of the Interior organised an extensive legislative review of the Aliens Act, even though the old act had only been enacted nine years before. According to the then Minister of the Interior Kari Rajamäki (SD) ${ }^{8}$, the review was motivated by the need to prepare the legislative means to confront the inflow of immigrants from the upcoming enlargement of the EU in May 2004 and to capitalise on the assets of international migration whilst eliminating any possible negative repercussions for Finland (PTK 40/2003 vp). The extension of the preparatory work over five years is partly explained by the parliamentary elections and change of the government in the middle of the process in 2003, but the delay can also be attributed to what Rajamäki calls the 'extensive, active hearing-process of national and international NGOs' (Ibid.).

The breadth over which this hearing-process was extended is indeed significant in the Finnish context, consisting of over 60 civic bodies. However, regardless of this extensive hearing-process, the memos of the parliamentary committees (most significantly, see Memorandum of the Parliamentary Administrative Committee, HaVM 4/2003) that assess the expert statements submitted by the human rights and migration NGOs indicate that the vast majority of the feedback (see, Ministry of Interior,

8 SDP = The Finnish Social Democratic Party. The other party abbreviations used in this paper are: NC, The National Coalition Party; SPP, The Swedish People's Party; C, The Centre Party of Finland; CD, The Christian Democrats; TF, The True Finns; G, The Green League of Finland; LA, The Left Alliance. 
The General Overview of the Statements Concerning Aliens Act Memorandum), although formally 'heard' in the preparatory process, has not been discussed and considered in the committees.

This indicates that extensiveness of the hearing process does not seem to correlate with any measurable increase in the political power or influence of the expert organisations that were heard. Moreover, of the few NGO-mediated revisions acknowledged and initially supported by the committees (such as the removal of the anomalous right to appeal from the Finnish Immigration Service or the right for recently graduated students to extend their stay while seeking employment), most failed to influence the letter of the law. In light of this, the official rhetoric of laudation pertaining to the role and the impact of this hearing-process in the preparation of the Aliens Act of 2004 can be disputed.

A key into understanding the nature of this highly selective incorporation of elements from the hearing process into the statute can be found in the Othering and national unity producing discursive practices visible in the preparatory process especially to the extent that similar discursive practices appear in the parliamentary and media debates. This boundary-work of national unity exhibits a unifying welfare state rationale. However, this boundary-work does not commonly manifest itself as direct opposition to some concrete or explicit policy measures. Rather, the impediments it creates for integrative accommodations tend to get formulated as assertions for distinct and particular forms of national unity that can then be used as a basis for various policy measures. One of the paradoxes of these assertions of unity is that this unity is simultaneously perceived as independently existing but also requiring support from the state in the form of an officially articulated legislative regime that alleviates the impact of the supposedly immigrant-induced increase in heterogeneity.

In the following we identify four discursive frames manifesting this topdown rationale of a national legal control of the perceived immigration-induced heterogenisation. An awareness of the national unity discourses that consistently frame immigration debates on various levels enables critique and alterations in a way that can anticipate some of the most typical hindrances that the welfare-state context may facilitate in the development of a more accommodative integration regime.

Our material points to the conclusion that immigration is regarded as a catalyst in the heterogenisation of values, which advances societal change and inequity and that attains specific negative attention in the analyzed discourses. We suggest that it is against this tendency that national unity is being reinforced with four key discourses that span the top-down continuum from the preparation in the ministries, to the parliamentary debates, to debates in media and internet fora. The four discursive frames considered in our analysis can be illustrated and linked together as indicated in the graph below: 


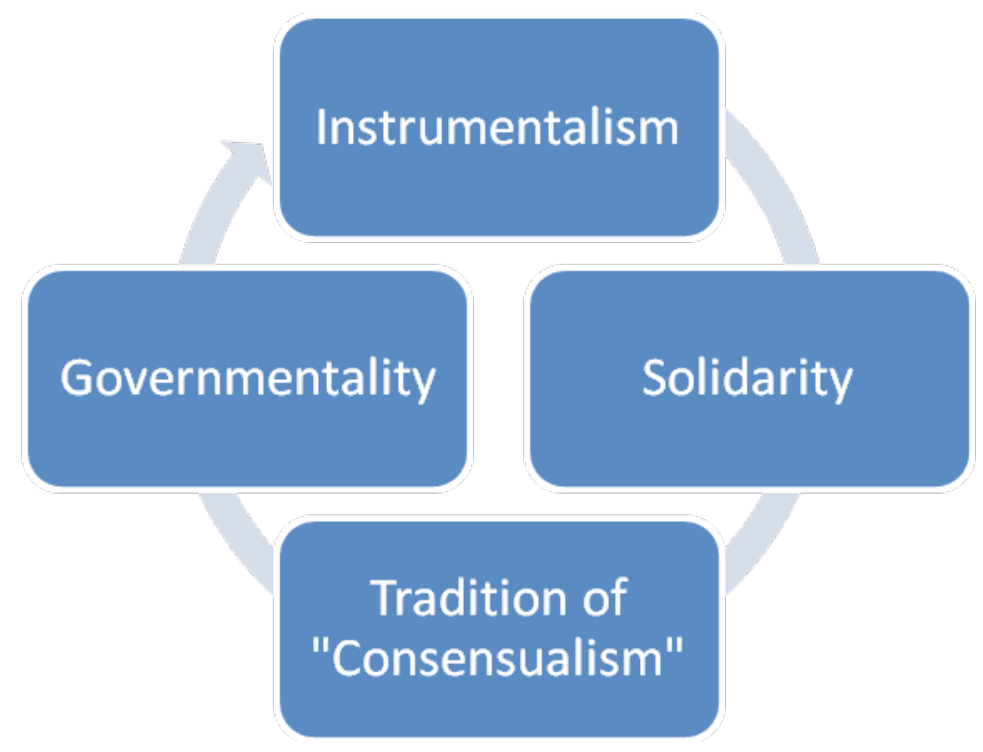

Figure 1: Top-down discourses exhibiting unity-producing rationale in a welfare-state context

The first frame we call 'instrumentalism' since there appears to be an inclination to portray the immigration question as one of instrumental management of pros and cons in which minimising the cons gets a significant priority. An example of the use of this frame can be found in the account of Minister of Interior Rajamäki, who first presents the governmental bill to the parliament. According to Rajamäki, reaping the benefits of immigration must be subject to minimising its ill effects to the greatest possible extent:

[T] he positive aspects of the cross-border migration flows had to be capitalised on while keeping its ill effects as small as possible. [...] The government considers it important that the motion for the Aliens Act will be given to the parliament [...] as soon as possible with the aforementioned justification. (PTK 40/2003 vp) (a).

While it is only logical to try to minimise the ill effects of any societal phenomenon, the direction of this instrumentalism is significant. Namely, a rationale in which minimising the disadvantages would be subject to receiving the maximal benefits from immigration, forms a scenario very different from the one proposed by Rajamäki where reaping any benefits is first and foremost subject to minimising the perceived disadvantages. This primacy of averting ill effects amounts to a markedly assimilationist hierarchy in the conceptualisation of the administration of immigrant affairs. It is also strictly at odds with the more multiculturalist accounts - favoured by many minority NGOs - that regard sustainable immigration as primarily a process 
of give-and-take. ${ }^{9}$ Rajamäki's address suggests that the prudent way to organise immigration is rooted minimising the 'gives' rather than maximising the 'takes'. This strategy suggests that the official stance emphasising national unity is not particularly keen to embrace the aspect of mutual exchange and compromise in immigration, even when there are some quantifiable assets to be secured.

The second frame, solidarity, pertains to a common, ostensibly civic (i.e. nonethnically based) unity which is regarded as an important means for limiting sociocultural stratification. This is a highly salient frame to be considered here because, as noted earlier, stratification as a central negative effect from societal heterogenisation is commonly interpreted as being due to increased immigration. Juxtaposition of national security and the immigrants' rights in the preparatory material is a clear manifestation of this assimilationist solidarity frame. Rajamäki nails down this dichotomy in passing:

The most fundamental aim [of the revision of the Aliens Act] has been to find a balanced whole where Finnish internal security as well as the rights of the alien residents and immigrating aliens are taken into consideration. (PTK 40/2003 vp) (b).

While Rajamäki argues that it is possible to balance between the two considerations, the fact that he regards them as the opposing ends of a spectrum is telling. Since Rajamäki does not consider it necessary to explicate why and how exactly national security requires compromises pertaining to immigrants' rights and vice versa, one can only assume that the connection is somehow direct and self-evident; that the existence of an immigrant minority population with a wide range of rights is in and of itself a challenge to national security in terms of the security of a particular form of nation - the allegedly shared experience of security in Finnishness.

The validity of this assessment is reinforced in the study by the Finnish Institute of Migration, ordered by the Ministry of Labour in 1999 and used as background information in the preparatory process also for the Aliens Act of 2004. In defining the term 'ethnocentrism' as the willingness to live without social disruptions caused by the presence of outsider practices, the governmental document also bluntly states: 'Finns are mostly ethnocentrists' (Ministry of Labour, 15.9.1999). This perceived ethnocentrism as a commonly shared trait in the electorate renders Rajamäki's curtness intelligible. An inflow of immigrants with a set of rights (also cultural in nature) does challenge the security of the continuity of certain national practices to the extent that they have enabled by the relatively homogenous ethnic background (such as singing religious hymns in festivities in public schools). These practices are, by definition, attributed an inherent value within an ethnocentric mindset. However, what makes solidarity a problematic discursive frame is that emphasis on 'solidarity'

9 See, for instance, Taylor 1992; Kymlicka 1995. 
may entail support for practices and ideas that are only indicative of a pre-existing solidarity and as such possibly everything but solidarity-building.

The third discursive frame, 'tradition of consensuality', is perhaps the most complex of the frames and refers to a practice that has for decades been considered central in Nordic decision-making based on proportional representation (see, for example, Lepola 2010). Our data indicates it is also commonly invoked as an element reproducing national solidarity. Indeed, the power-sharing and majority-restricting elements considered to be in the core of consensualism ${ }^{10}$ do have many links to bridging solidarity functions (see, for instance, Schuller, Baron and Field 2000:10). The practical reality is somewhat different, however. While the preparatory material of the Aliens Act that seeks to portray the traditional Finnish decision-making system as one incorporating consensuality at its core, the attempts to apply such principles in more heterogeneous and diverse contemporary contexts are questionable at best. Legislative counsellor Jorma Kantola - the civil servant in the Ministry of Interior in charge of the preparation of the Aliens Act - challenges the critique according to which minority opinions were not acknowledged in preparation with a particularly idiosyncratic argument:

Some NGOs have been disappointed in the Aliens Act claiming that it failed to note opinions expressed by the minorities, but that is not true. All statements were duly noted. But it is not easy to implement minority opinions when the majority disagrees. (Interview of Legislative Councellor Jorma Kantola from the Ministry of Interior in 5.12.2008) (c).

This indicates that while the importance of this consensual tradition of decisionmaking is asserted in the studied discourses, the actual history of relatively high ethnic homogeneity furnishes the system with a distinct majoritarian bias. Instead of forming new ways to conceptualise and implement consensualism in a more heterogenised societal setting, old ways of governance are still referred to in terms of 'consensualism'. This means that power sharing is understood only as a practice taking place among the various factions inside a pre-existing sphere of solidarity but quickly skipping the invitations to mutual compromises by the immigrant Other that appears external to the sphere of solidarity.

A similar dichotomy between hearing a member of a minority group and acting upon what is heard is present in many places in the Act itself. A good example of this is presented in a memo by the Administrative committee stressing the importance 'to evaluate the entirety of the child's best interests, also by taking into consideration the opinions, wishes and individual needs of the child, where appropriate [...]'(HaVM $4 / 2004 \mathrm{vp}$ ) (d). While hearing minority members in issues concerning them has

10 For a distinction between the ideal types of majoritarian and consensus democracies, see Lijphart 1984. 
certain legitimising value, the substantial purpose for hearing a minority (member) both in preparation and implementation of a law remains unclear when weighted against this allegedly consensual, but actually majoritarian practice. To the extent that the officially recorded minority perspectives coincide with the majority ones, the practice of hearing minorities does create a semblance of a multiculturally minded administrative process. It is, therefore, only when the minority views would challenge the majority's way, where the national security is nested (as Rajamäki alluded), that the assimilative bias we suggest can be observed.

The last frame, governmentality, is not related to any Foucauldian framework. Rather, governmentalism entails the norm of wilful subjection to the decisions made by the government. This norm is legitimised, in part, through the assertions of consensuality in a political decision-making system, thus establishing a threshold for any objections against purportedly commonly reached decisions. Effectively, governmentalism as a discursive frame attaches a strong positive, republican value in yielding to administrative control by a paternalist welfare-state. This is established by portraying such control as adding to the person's own capabilities to exercise power through the state. This value of governmentality is highly desirable from the instrumentalist point of view, because the norm of submission sustains a power-wise economical form of governance.

The issues concerning the well-being of the immigrant minorities that the parliamentary committees raise are commonly considered possible to be remedied through relatively paternalistic state-mediated interventions. Such interventions, of course, belong to the core operating modes of the welfare state, which is sometimes portrayed as the 'People's Home' (Esping-Andersen 1990:67-69) and are not peculiar to Finnish immigration policy per se. This fact, nevertheless, only underlines the saliency of these welfare considerations in the endeavour to integrate immigrants into a welfare-state. The motion for an alternative Aliens Act by Esko-Juhani Tennilä (LA), although opposed by the Administrative parliamentary committee, suggested an exemplary paternal expansion. According to him, in labour disputes where a foreign citizen is a party, the state capabilities to intervene should be expanded by effectually allocating many minor complainant offences under public prosecution by furnishing the labour market organisations with the right to sue (LA 163/2003 vp).

It is worth noting that here Tennilä argues for corporative representation of immigrants in courts instead of a legally protected right for the immigrants to seek legal counsel from the said organisations. It seems therefore that the measure is not primarily intended to help immigrants to integrate but rather to 'take care' of them, while also making it more risky for corporations to hire foreign labour in comparison to native workers. This case suggests that the accentuation of the paternalist tendencies of this 'welfare Finnishness' is seen as more legitimate when applied to the immigrant minority population. While extrapolation from a single case is always subject to many caveats, in the light of these considerations, it becomes interesting to assess in more 
detail the extent to which immigration is used to expand the scope the welfare state's corporatist responsibilities. ${ }^{11}$

It must be noted that while this fourfold framework is illustrated through examples from the preparatory legislative context, each of the contexts - the legal jargon, the parliamentarians' performances and the mediated civic debate - would enable quite divergent ways to interpret the frames. This means, of course, that using a unique framework for each of these contexts could also be justified. However, as we will illustrate in the following, the four national unity discourses identified do permeate through the dimensions we analyse, even if they manifest in different forms depending on the context. Moreover, we do not seek to exhaustively describe the three dimensions but rather look for similarities between them that are pertinent to national unity constructions in a welfare state context. Therefore, the uniform application of this four-fold framework allows us to pursue this goal and show how exactly this welfare state rationale of national unity can delimit the ways immigration questions are debated at various levels of society.

\subsection{Parliamentarians' constructions of national unity through the state}

It is commonly accepted that the plenary discussions of the parliament have little relevance to the policy-level of actual political decision-making. The debates serve other functions - those of political performance, symbolic representation, and public ideological and argumentative contestation (see Pekonen 2008, Turja 2008). Taking this understanding of the parliamentary discussions as the point of departure, this section examines claims made about the proper role of the state vis-à-vis immigration and foreigners in the plenary debates on the 2004 Aliens Act ${ }^{12}$, complemented by an analysis of the 1999 Integration Act from roughly the same time period. ${ }^{13}$ In total, the

11 An alternative way to conceptualize the immigrants' role in the development of the welfare state is to see immigrant minorities as a catalyst through which a variety of conflicting Finnish agendas can be advanced. For instance, the next section considers Paula Kokkonen's (NC) speech (PTK 74/2002 vp) where Kokkonen warns of the mistake of building the integration system into 'another totalitarian system, building of which we have been too fond of.' This could be read as an integration-mediated argument for dismantling some of the existing welfare structures considered by the right wing parties as 'totalitarian'.

12 As a measure to restrict the size of the material, debates on the government bill (HE 265/2002 vp), which expired due to the parliamentary elections in 2003, were not included.

13 A follow-up debate on the Government Report on the implementation of the law (VNS 5/2002, HaVM 20/2002), 5.2.2003. In contrast to the Aliens Act debates, this debate stems from the time before the 2003 general elections. The debate was included in the material in order to diversify the empirical base. Nevertheless, the Integration Act debate constitutes only a small share of the overall text material and is consequently drawn on less than the Aliens Act debates. 
empirical material covers six debates of various lengths from a fourteen month period in 2003-2004. The material contains over two hundred addresses by almost seventy parliamentarians. Fourteen parliamentarians feature as especially active debaters in this material, most participants addressing the floor only once or twice.

The purpose of the parliamentary debate on the Integration Act was to approve a government implementation report; the discussion largely deals with general aspects of good immigrant integration and contains relatively few addresses which are confrontational in tone. The proposed bill for the Aliens Act is a matter of a different nature. The material is saturated by a persistent disagreement about a few different aspects of the law, especially issues related to asylum seekers from the 'safe countries', the 'grey economy' and the access of foreign labour to certain seasonal jobs without work permits. Other recurrent themes include foreign degree students' possibilities to stay in Finland for work and the rights of asylum seeking minors. While several parliamentarians expressed trust in Minister Rajamäki's leadership, some criticised both the bill and the preamble for shortcomings. It is acknowledged in the discussion that much of the disagreement springs from the difference in values and priorities between those who stress the security and economics of the nation-state and those who take human rights as their point of departure (see Hiltunen (SD) in PTK 39/2004).

In the following, we aim at detecting how the four frames established in the first section of this chapter are present in the debate material. We seek to demonstrate how parliamentarians construct aims and roles for the state, emphasising the frames identified earlier. In the empirical data covered in this section, these frames translate into: 1) solidarity towards Finns (selective solidarity), 2) calculative management of migration (instrumentalism), 3) the strong embrace of the state (governmentality), and 4) conceptions of the sound decision-making process (tradition of 'consensualism'). While the relationship between the discourses within our set of data remains as suggested in the previous section, the frames are discussed in a different order in this section than in sections two and four. This is because the parliamentarians typically debate in a manner that establishes solidarity towards fellow citizens (or towards the 'weak refugees' as in the counter-discourse) as the justification for the reasoning within other discursive frames. The qualities of a sound political process, on the other hand, receive relatively little attention in this material, and thus, that frame is discussed last. Moreover, we employ an approach which concentrates especially on talk that represents migration as a source of problems for Finland beyond most other challenges the country has to face. In order to complement the main analysis, we also point out some instances of parliamentarians proposing alternative conceptions to the dominant ways of discussing the topics at hand. 


\subsubsection{National solidarity}

Growing international migration increasingly challenges states to deal with the question of who the state is responsible to protect and care for. Struggles to reinforce old boundaries of solidarity and establish new ones are also present in the Finnish parliament. Notably, the debates on the Aliens Act reveal two distinct approaches: the idea that as a sovereign nation Finland can legitimately care more for Finns than for immigrant Others, and a challenge to this discourse which emphasises wider responsibilities, international conventions and human rights. Ulla Anttila (The Green League, PTK 39/2004 vp) formulates this latter position neatly: 'As to if Finland is quite a separate state [...] I don't myself quite believe in it.' (e). This more rights-oriented way of arguing about the relationship between the Finnish state and foreigners cannot be described as marginal as it appears as a strongly defended line of argumentation alongside the dominant, more restrained view of the state's responsibilities. Due to our analytic focus, however, we concentrate below on describing the dominant frame of national solidarity.

The task of this parliament [...] is to take care of our own citizens. In certain situations, taking care of our own citizens provides that we receive [...] foreign workers [and] refugees [and] take care of them. It's a part of the whole. But [...] the primary task is that we in this hall decide first and foremost on the problems of Finnish people. - Ahti Vielma, NC (PTK 39/2004 vp) (f).

Finland and Finns always have the right to decide who and how many come here. It is our task and our right in this country, as the Turkish have in Turkey, Slovaks in Slovakia and Swedes in Sweden. This is a national question. - Timo Soini, TF (PTK 39/2004 vp) (g).

In a world where the state has lost many of its previous powers to control movements of capital and means of production, the management of people seems to lend itself to the discursive reproduction of sovereignty, a conception evident in the quote by Timo Soini above. According to the MPs following this line of argument, national self-interest - aiming at the best possible (economic) outcome for Finns is natural (e.g. Zyskowicz PTK 39/2004 vp). In a very clear form, this preference is manifested in claims that labour immigration should not be excessively encouraged or at all considered as long as there are Finns out of work (e.g. Rönni 39/2004 vp). Correspondingly, the countries of emigration are portrayed as sovereign entities, and recruitment from areas that suffer from emigration is condemned. This view can be exemplified by a quote from a Social Democratic MP in the Integration Act debate who establishes that 'it is not either in the interest of Finland that we would coax the best work force of the small Estonia to come here, rather it [the work force] should be there, taking care of patriotic duties.' (Skinnari PTK 195/2002 vp) (h).

Parliamentarians also attach themselves to the frame of national solidarity in less explicit ways. The fact that Finnish citizens are consistently referred to in 
the parliamentary debates simply as Finns (suomalainen) - a word also bearing a connotation of Finnish ethnicity - connects the idea of solidarity between citizens of a state to solidarity between people of shared ethnicity (see Lepola 2000). Pride in the nationally developed structures, distinctiveness of other cultures and the priority of the current arrangements (in contrast to new ones) are hinted at in expressions such as 'rules of the game of the Finnish labour market', 'norms of Finnish society' or 'becoming a part of the normal Finnish every-day life', when appearing in contexts where the idea would be comprehensible without the national attribute or could, for the sake of the main point, be replaced by another word (e.g. 'rules of the good working life'). The idea of putting the Finns first runs through most of the other topics discussed in this section; in particular, this idea is clear in both the discourse of costs and gains of immigration and in that about racism.

\subsubsection{Costs and gains}

The costs-and-gains frame is frequently employed in the debates. Calculative approaches to migration and diversity appear in the material as references both to positive potential and to negative expenses. While it is possible to see the references to 'resources' as opposed to articulations of the 'costs', the two approaches share the logic of measurability and rationality. Partly, the economic-rationality discussion relates to the efficiency of the public systems - for example claims that the municipal economies should not be burdened further or that it would cost little to expand service in English. However, the parliamentarians also try to assess the qualities of migrants. While the economic potential carried by migrants is particularly lucidly acknowledged in the Integration Act debate, the concern about costs is pervasive in the debates on the Aliens Act.

The discourse of direct gains incorporates articulations of the need to import experts and specific groups of skilled workers in order for Finland to perform economically well. This point is presented in a straight-forward manner, and extends to foreign degree students, whose possibilities to stay for a job-search in Finland after graduation are restricted by rigid residence permit rules. Not being able to stay to work renders the investment into these people's (often tuition-free) education unproductive. A more subtle register for articulation comes into play when considering the potential gains related to migrants who are currently outside the labour market. For those who emphasise the value of migrants, the arguments deal with the future needs at hand, recognition of the skills instead of mistrusting applicants with a foreign background, and seeing education of immigrants as an investment rather than as a cost. This idea of resources that are yet to be discovered is captured in a quote by a Centre MP: 
Finland does have a comparably short immigration history. Maybe that's why we are not yet fully capable of recognising and utilising the social, linguistic and cultural know-how brought by immigrants. Taking into productive use of this existing but untapped resource would serve Finland on various fronts. - Paula Lehtomäki, C, (PTK 195/2002) (i).

Things get more complicated when we turn to the cost-side, since not all costs are equally negatively loaded. Even promoters of the strictest entry policy are quick to underline that those in 'real distress' should be allowed to stay. To discern between the worthy and the scam asylum seekers is one of the core elements of the costs discourse pertaining to individual migrants. MPs engaging in a disapproval of the undeserving asylum seekers, operate with clear categories of 'real' and 'unreal', as illuminatingly expressed by a Social Democratic MP:

If only someone would bring [to light] the figure in a quite straight forward way and tell the truth about who are real refugees and who have only come in the hope of better [life] [...]. - Tero Rönni, SD, (39/2004 vp) (j).

Legitimate distress is not often very thoroughly defined by those referring to it. The expression 'life in danger' appears in this connection (Soini PTK 45/2004 vp), clearly not implying endangered subsistence due to economic or social but political reasons. It is clear, nevertheless, that the vast majority of asylum seekers are seen by these debaters as undeserving and directly consuming the public budget. For example, the Central and Eastern European Roma may be discriminated against, but not persecuted - an understanding which a few parliamentarians, nevertheless, do strongly challenge.

The argument of those focussed on the false asylum cases has two facets. On the one hand, the welfare provision to ungrounded asylum seekers is claimed to translate directly into diminished public expenditure on deserving Finns. On the other hand, the resources of the reception system are viewed as relatively stable since the sluggishness of granting protection to those worthy of it is said to be caused by the burden of processing the bogus applications: 'The more we have people groundlessly applying for asylum, who only have arrived in order to seek access our social welfare, the less resources we are left with to receive those individuals who would really be in need of asylum.' (Hemmilä, NC, PTK 39/2004 vp, see also Paajanen and Oinonen in the same debate) (k). These calculations construct the asylum seeker as an ultimately immoral individual who whittles away the welfare of Finns in need and stands in the way of a deserved new life of the few truly persecuted applicants. In a similarly dual argument, the substandard wages paid to foreign workers are referred to both as a violation of the rights belonging to the foreigners themselves (cf. worthy asylum seekers) and a reason for the economic suffering of many Finnish workers (see PTK 16/2004). 


\subsubsection{The strong embrace of the state}

Closely related to the frame discussed above, the next frame relates to the understanding of the state as a potent actor capable of governing and administering various aspects of life successfully. This notion of the internally strong and legitimate state manifests in claims by the parliamentarians which call for more state responsibility within Finnish society, at times to the extent that these wishes could be characterised as paternalist. Responsibility is notably called for in relation to two themes: the preservation of high morals of the citizens through state regulation, and the education of immigrants.

It is very important to act against the grey economy, because if it is allowed to grow [...] it almost inevitably erodes Finnish working morals, Finnish ethics, our conduct. This particularly high ethics, that taxes are paid and fines are paid [...] has, after all, been born in the course of hundreds of years. This kind of moral ethics can also weaken relatively quickly if space is given. - Kari Uotila, Left Alliance (PTK 16/2004 vp) (1).

The claim to protect the morals of Finns appears to address two topics, one related to work and the other to racism. Firstly, a clear division is established between orderly Finnish work and the 'wild', 'grey' economy attached to foreign workers. This is expressed, among other instances, by Matti Kangas' (LA) illustrative expression 'ungoverned immigration messes up the labour market' (PTK 40/2003 vp) (m). His choice of verb ['sotkea', to stain] carries a connotation to dirt thus linking disorder and impurity (see Douglas 2005 [1966]), the potential for which the labour migrants carry within themselves. In general, the Finnish nationality of the employers allegedly committing breaches of laws and agreements is not referred to. This pattern is, however, broken by a Left Alliance representative, stating that it is the Finnish employers who exploit labourers legally entering Finland (Laakso (LA), PTK 40/2003 $\mathrm{vp)}$. This address can be read as an alternative counter-position (capitalist-worker) to the one focussed on nationality (Finns-foreigners).

The morality of ethnic Finns is further presented as precarious and threatened by outside forces through the references to racism. Racism is called a 'sickness' (Tiusanen, PTK 99/2003 vp) which should be strongly objected to - and the means proposed is the control of immigration and monitoring of foreigners within the country. It is intriguing that the alleged prevalence of racism can be drawn on in this discussion to make legitimate claims about restrictive policy. To try to discern whether the talk about racism demonstrates a genuine concern for discrimination or whether racism is simply rhetorically employed as a deterrent is not of relevance for our analysis.

In the addresses concerned with racism, both the 'grey' foreign work force and the groundless asylum seekers present a moral hazard: It is argued or feared that 'the people' (Finns) cannot accept the public spending on the asylum system in which many applicants are not eligible (but 'ungrounded'), and/or that 'the people' cannot accept being offered lower pay following from the 'dumping' of wages due to unfair foreign competition. Consequently, the citizens are said to develop undesired 
racist attitudes and resentment towards all foreigners, including the innocent ones. ${ }^{14}$ In an extreme depiction below, a MP even links domestic violence and the management of immigration policy. Again, the state is called for to act to manage immigration to guard the well-being - the morals as well as material security - of Finns.

[I]f we can handle this foreigner policy right, it will also effectively prevent the furthering of racism, which already now smoulders [...] kind of hidden in many places and in people's minds, but doesn't manifest itself. We [the Finns] are the kind of people that we grouse and grouse and then go behind the house and give the wife and the kids a caning, and talk like 'I would have wanted to say it in the meeting and I should have told those people home truths for once', but as one doesn't dare to say, they go behind the house and do that [the caning]. [...] [W] hen racism really breaks out, like it did in Joensuu, it was indeed because too many folk [foreigners] pack in one place and people [Finns] feel they are now in an unequal position. - Tero Rönni, SD, (PTK 39/2004 vp) (n).

The racism issue was debated in conjunction with the Aliens Act. The Integration Act debates, however, show another side to the frame that highlights state involvement in the citizens' lives. Here, the state is attached to connotations of a benign actor with responsibilities towards the education of newcomers. The Integration Act particularly concerns resident foreigners who are in weak positions in society individuals with a refugee background, for example. Unlike the Aliens Act debates, the right to stay is not disputed in the Integration Act debate, and the discussion revolves around the conditions for the newcomers' 'integration' into society. In other words, while the most debated type of immigrant in the Aliens Act was a scheming asylum seeker, the 'protagonist' of the Integration Act debate is presented as rather inoffensive.

In fact, these migrants are often expected to have very low capabilities. Making an Integration Plan is, for example, said to aim at 'giving the immigrant real possibilities to learn how to manage one's own life and attain the skill and ability to make a living in Finland' (Tiura (NC), PTK 195/2002, our emphasis) (o). The immigrants are to be schooled, cultivated, made aware of their position as citizens in the society and taught to trust the public authorities as Finns do. The role of the state thus becomes defined primarily as one of a caring agent especially towards youth and immigrant women who care for their children at home. Nevertheless, the control function - the obligatory nature of adaptation to Finnish society - is also occasionally highlighted. For example, the leader of the True Finns party suggests it would be best to assign an 'individual [...] overseer to each immigrant starting in an integration programme' (Soini (TF), PTK 195/2002 vp).

14 With different emphases and angles, see e.g. Karhu PTK 39/2004 vp, Kangas PTK 40/2003 vp, Lahtela, E. PTK 39/2004 vp, Peltomo PTK 40/2003 vp, Salo PTK 39/2004 vp, Satonen PTK 39/2004 vp, Soini PTK 45/2004 vp, Tennilä PTK 45/2004 vp, Rajamäki 39/2004 vp. 
There is also a focus on the need for the public system to be perfected, especially in relation to coordination between offices and levels. In the following quote, it can be noted that even a vocal NC representative, who would normally call for some form of state retrenchment, actually expresses her support for the state's involvement in integration work together with the third sector and the 'integree' him/herself (see Tiura, PTK 195/2002 vp). The strong system orientation is also critically noted by the parliamentarians themselves, as in the quote below:

It feels like, to officials, ministries and various organisations, the immigrants are only compulsory objects of existence who have to be guided or advised to have these [Integration] Plans made. Heli Paasio, SD (PTK 195/2002 vp) (p).

\subsubsection{The sound political process}

The frame of 'consensualism' refers to a tradition of doing politics that is particularly pertinent to Finland as a Nordic welfare state (Lijphart 2008:93). This tradition highlights inclusion in the policy process that, nevertheless, does not necessarily lead to a decision and output that would accommodate minority views. Rather, the bargaining takes place between alternatives backed by the powerful mainstream actors.

This ambivalence is illustrated within the parliamentary debates material in Minister Rajamäki's presentation of the Aliens Act bill (PTK40/2003). The bill had been presented once already, but had expired due to general elections. When bringing the bill to the parliament for the second time, Rajamäki referred to the extensive hearing round conducted previously and motivates not repeating that part of the preparation. His argument was that the Government was already aware of the different viewpoints of the various NGOs and others they had 'actively heard' (although the validity of this can be questioned on the basis of the findings in the previous section). On the one hand, much time and effort had been put into collecting these views, but on the other, the Minister seemed to regard the long preparation procedure as a burden rather than an asset.

The Integration Act debates also contain a few references to immigrant participation' which relate to this frame. Claims are made for more active participation and cooperation with public authorities by immigrants, but it is left open to what this participation would mean in terms of influence. An example of this type of talk can be found in an address by a Social Democratic representative who claims that 'civic and immigrant associations should be given the possibility to participate in the preparation and implementation of the municipal integration programme, if they so wish' (Kähkönen, PTK 195/2002 vp) (q). This proposition seems to promise much but does not suggest concrete ways of putting such ideas into practice. The only exception to the pattern within our material can be found in an account by a Left Alliance 
representative who specifically considers quota based representation in municipal committees for migrants and refugees arranged through the parties (Turtiainen, PTK $195 / 2002 \mathrm{vp})$. The fact that no other comparably concrete suggestions appear in this debate indicates that consensual ways to implement 'immigrant integration' are not considered in the parliament.

\subsection{A macro-societal approach to immigration topics - media discourses and internet debates}

The media stand in a dialogical relation with the social environment, where institutionalised practices are conceptualised and discourses of the everyday-life reified - simultaneously functioning as societal actors per se. For the purpose of studying grass root level rhetoric, however, media articles represent only a narrow selection of opinions, as letters to the editor pass through strict qualification systems. The possibility of expressing opinions publicly through print media is thus restricted, and this lack of anonymity strains out the harshest and the most polarizing attitudes. Internet-forums therefore provide a better means for this purpose of 'venting'. To gain insight in the public discourses we have analyzed both media articles and internet debates related to the media topics - as the same themes appear at both levels, we do not present these separately.

Since our media material is related to legislative aspects and revolves around societal practices, it is important to emphasise the specificity of the findings of this study - media discourses related to immigration and Finnishness in general might address different aspects. To a large extent, the analyzed texts approach the topic through macro-level aspects of immigration discourses, focussing on structures and bypassing micro-sociological issues. The societal changes occurring in the period, from 1999 to 2009, are partly visible in the media articles. The terminology used in the earlier texts is unclear and seems unfamiliar to the writers, as also pointed out concerning the Parliament debates. Refugee, immigrant, foreigner and migrant $^{15}$ are largely used synonymously, even within the same text. A change can be observed during the discussions on the Aliens Act 2004, where also the frames and approaches to the theme are more versatile. The vocabulary used in 2009 shows a more 'professional' approach. The concepts are more precise and the Finnish term for integration, 'kotouttaminen' [literally: homing], relatively new in 1999, is in the 2009 texts used with confidence and familiarity. Signs of uncertainty concerning certain concepts, however, continue to exist in the articles from 2009.

15 [Pakolainen, maahanmuuttaja, ulkomaalainen ja muuttaja]. 


\subsubsection{The meta-discourse: Finnishness through boundaries}

Differences in the discourses appear between the legislative processes; when discussing the Immigration Act - both 1999 and 2009 - immigration is conceptualised through differentiation, positioning 'immigrants' as distinct from the notion of Finnish society, as noted also within the parliamentary debates. The dichotomisation is not expressed explicitly, but is rather present as a tacit assumption; a perception of 'the immigrant' as the stranger ${ }^{16}$, the Other - essentially different and separate from the familiar and natural - 'Finnish society' (see Pietikäinen 2000; Horsti 2005). This aspect is not as visible in the texts discussing the Aliens Act (2004), where the topic is approached from a broader perspective and placed in a less nationally dominated context, e.g. by comparing European policies and discussing supra-national borders and Schengen. This is in principle self-evident, as the notion of integration directly relates to the society in question. The following quotes illustrate how the conception of the 'immigrant' is dissociated from the conception of Finnishness.

To get a job is almost the only way for an adult refugee to get involved in the Finnish every-day life and to adapt to their new country [...] when learning the ways of the country. (HS -Pääkirjoitus, 15.7.1999) (r).

During the waiting period, the immigrants do not necessarily get any information about Finnish society. [...] 'As a premise, people do want to integrate.' (HS quoting Ministry of Internal Affairs official -Kotimaa, 21.12 2008) (s).

Evergreen stereotypes of 'the immigrant' are present in the differentiating rhetoric there are however clear differences between the rhetoric in media texts and internet forums; in the articles the stereotyping is subtle, in the forum comments openly articulate racist opinions. Stereotypes appear as binary relations coupled to their respective poles: 'the lazy immigrant' or 'the helpless immigrant' vs. 'the capable society'; and the counter-discourse 'the capable immigrant' vs. 'the structural failures of society'. Thus 'the immigrant' is always mirrored against the perception of 'the Finnish state' as an authority. The stereotype of 'the lazy immigrant', an image appearing also in the parliamentary debates, concerns a view of immigrants as unwilling to work, lazy at learning the Finnish language or disinterested in co-operating with the system, which is perceived as striving to 'help the immigrant integrate'. This role is prescribed to the Finnish state also in relation to the view of the immigrant as feckless and incompetent.

16 The stranger, in the terminology of Georg Simmel, becomes connected to a group simultaneously being distanced from a We-collective. This group is perceived through something similar to a normality principle - the norm is set by what is considered to represent the own collective, the excluded are represented through their difference. (see Simmel 1981.) 
The dichotomy of 'the capable immigrant' vs. 'the structural failures of society' is a counter discourse within the same macro-level thinking, where the system is blamed for unsuccessful employment and integration of immigrants. When discussed, the poor employment situation of highly educated immigrants is addressed by quoting a researcher stating that the main reason for the problem is the Integration Act that has been in place for ten years (HS Kaupunki, 10.6.2009). The notion of the immigrant is thus mainly positioned in relation to the Finnish society as a structure and to a lesser extent in relation to the notion of a Finnish population - Finnishness is mainly shown as an institutionalised political frame. In the following sub-sections we examine central frameworks through which immigration is approached - these frameworks are partly overlapping and not mutually exclusionary, but clarify different aspects of the macro-level orientated discourses on immigration.

\subsubsection{Management of the pros and cons of immigration - the instrumentalist frame}

Integration is important from the national economy point of view because non-employed immigrants only cause society expenditure and do not pay any taxes. (HS -Kotimaa, 21.12.2008) (t).

A frame visible at all levels - from the legislative processes to the political debates, media rhetoric and forum discussions - is the resource/expense way of approaching immigration questions. Within this instrumentalist frame, the frame of calculated Finnishness, immigrants are objectified and function as statistical figures or conceptual tools concerning societal management - as a means for the economic success of the society or as an expensive and demanding burden. Immigration is presented as a resource only in regard to economic benefits - other aspects are addressed in only a few texts from 2004. It is emphasised that immigrants become contributors to the economic development of society through successful integration. The main positioning of the notion of immigrants as resources is in relation to the need of the labour market as potentially contributing to the economic growth of the state. Regardless of the positive tone within this resource-approach, immigrants are in most cases objectified - statistical figures, denominated as, for example, 'a brilliant potential of immigrant background' (HS Pääkirjoitus 16.3.2009):

[...] a twenty-year old youngster brings 85000 FMk to the Finnish economy, a trained engineer, doctor or a nurse approximately 2,5 Million FMk. (HS -Kotimaa 19.1.1999) (u).

According to the South Savo TE-center, the total need of the labour force is 75000 persons in SouthEastern Finland by 2015. (HS -Kotimaa, 31.1.2004) (v).

Among the immigrants there are persons who really would like to work in jobs that correspond to their profession and for whom the search for work could be made easier by changing the legislation. [...] This means that we lose many good tax payers. (HS Internet forum; Alias: Ystävyyttä ja tasaarvoa kaikille, 9.6.2009) (w). 
The other side of this instrumentalist approach is the representation of immigrants as societal expenses; since in the Parliamentary debates, immigration is conceptualised in terms of costs and gains. The aim within this rhetorical strategy is to support the argument with statistical means. The figures are not mere numbers; they verify the viewpoints of the writers. The implementation of the Integration Act is presented as an economic burden and a huge effort overloading the municipalities with work and responsibility.

About 30 Million euro are used annually on immigrant education. (HS -Kotimaa, 21.12.2008) (x).

The local authorities have time until the end of September to make a plan for each who cannot get work by themselves. [...] Money was not allocated to the municipalities. (HS -Kotimaa, 31.8.1999) (y).

The rhetoric of the internet forums is more polemical. Immigrants are depicted as, by definition, incapable of contributing to Finnish society. Specifically concerning refugees the focus on expenses is central: the refugee is seen bringing in nothing and costing a lot. This aspect, clearly posing a problem for a development-oriented approach, is parried by emphasising the aspect of asylum seekers as not being permanent residents.

The refugees have probably little such work experience that they could apply here. (HS Internet forum; Alias: Ei koske käytännössä pakolaisia, 9.6.2009) (z).

[...] the refugees are secured temporary stay and their return home is secured. They will not become residents in the municipality. (HS -Kotimaa, 22.4.1999) (aa).

Education in their mother tongue is arranged for the children. 'The children learn a foreign language fast, and this may make their return to the home country more difficult.'[...]. Adults get training to the extent that they can cope here momentarily. (Ibid., quoting Ministry of Labour official) (bb).

\subsubsection{Immigration as societal threat - negotiating solidarity}

One conceptual angle appearing at all levels of our analysis is the notion of risks related to immigration issues from the societal perspective - both in connection to concrete problems as criminality and security, and to social cohesion, addressing the dangers of stratification and racist attitudes. A central theme in the internet debates is the hierarchical positioning of immigrants and the majority population in regard to social support; it is stressed that the responsibility of the state is primarily to cover the needs of the majority. By sarcastic statements and questions such as 'Which country will take us highly educated and top qualified unemployed Finns and support us?' it is argued that immigrants are getting the support the majority population needs, and 
would have the primary right to receive (HS Internet forum; Alias: Mikä maa ottaa MEIDÄT, 9.6.2009) (cc). The same theme is repeated in many varying formulations:

When will there be an initiative and an office for offering Finnish young people work that corresponds to education? (HS Internet forum; Alias: Koulutusta vastaavaa työtä meille suomalaisille, 9.6.2009) (dd).

This approach appears in the Aliens Act related discussions, but is less visible when discussing the Integration Act. In the latter, comparisons to problems in other European countries are brought up, emphasising the importance of preventative measures.

European Immigrant Suburb Problems to be Avoided in Finland. (Heading in HS -Kotimaa, 11.1.2009) (ee).

In the 1980's, there were extremely few foreigners in Finland. There were small groups of newcomers and they were not regarded as a socio-economic threat. During the recession fears appeared that there will be a lot of them [...] (HS quoting researcher -Kotimaa, 16.9.1999) (ff).

The quote above exemplifies how racism is viewed from a cause and effect perspective within the social system orientated discursive framework of the discussions in our material, bringing in the social structures as the explanatory and underlying force.

\subsubsection{Prioritising 'us' - the precedence of the majority}

Our way may not be the only right one, but it is the one that the majority of Finns want to be applied in this country. (HS Internet forum; Alias: Thors erotkoon, 2.6.2009) (gg).

This frame is applied to a vast scale of issues - integration should happen on the terms of 'the host society'; education, subsidies and aid concerning participation in the labour market should be primarily targeted towards the majority. The decision making power over who is allowed into the country and who is allowed to stay, is the state's, as the authority of the majority population - With certain preconditions, the state can decide who may settle in its territory (HS -Mielipide, 9.3.2004) (hh). This prioritising rhetoric was primarily present in the discussions prior to the Aliens Act, particularly in explicating the sovereignty-emphasising premise for the system of accelerated returning of asylum seekers.

Minority and majority unemployment is a central themein theinternet discussions, conceptualised through conceptions of fairness and unfairness. Here the selection of 'most qualified' is emphasised as synonymous to a fair procedure. However, little thought is given to the cultural construction of the category of the 'most qualified'. The consequent bias towards Finnish candidates could be avoided by adopting some 
other, perfectly reasonable conceptualisations of these qualifications in cooperation with the immigrants themselves.

It is not easy to correct the situation as the unemployment of Finns is also high, but according to the law, the most qualified applicant should be chosen. (HS -Pääkirjoitus, 15.7.1999) (ii).

I do well understand if an employer is reluctant to employ an immigrant. As long as we live in a market society an immigrant is more of a risk than an opportunity or possible strength to many companies. (HS Internet forum; Alias: Elämme markkinoiden ehdoilla, 9.6.2009) (jj).

\subsubsection{Integration through legislative policies - immigration from a governmentalist perspective}

A perception of the state as the capable and trustworthy actor through which integration and other immigration-related aspects are manageable, runs through all the frames discussed in this chapter, and on all discursive levels analyzed within this study. Reified in its most distinct shape - the conception of the Finnish system within a paternalistic frame - the role of the legislative structures, as law and practice could be compared to the role of a parent, a helpful and capable actor also capable of punishing when needed; the carrot and the stick embedded in the societal structures. Through institutionalised practices, 'the willing immigrant' may become a member of society, but will lose benefits if not acting in accordance with the societal premises.

[...] training plans are made for the migrant. If the migrant does not want to participate in the training her/his benefits will gradually decrease (HS -Kotimaa 19.1.1999) (kk).

[...] the integration legislation wisely demands that refugees are brought to a more diversified interaction with Finnish society. The newcomer commits, in exchange for the support she/he gets, to learn the language of the country, to complement her/his professional skills and acquire other necessary information to be able to make a living for her/him and participating in life in other ways. (HS Pääkirjoitus 15.7.1999) (ll).

An aspect appearing both within the parliamentary debate and the media discussion is the view on the role of the laws in question as existing primarily for the sake of the majority population. Simultaneously seen as a functional means for placing the immigrant in a majority defined position in society, these laws are perceived as concretising the duties and rights of the immigrants, thus securing authority over Otherness - the power to define the criteria for acceptance. Through measures at the decision making level, different aspects of immigration are made manageable - from 'successful integration' to societal membership as a means of combating racism. 


\subsubsection{The media and internet discussions as a reification of the institutionalised policy-oriented discourses}

The media and internet discussions create a vague picture of the institutionalised integration system. It appears as simply a specific terminology - an institutionalised conceptual tool framing societal practices. The picture painted through the discussions related to 'integration' bears resemblance with to assimilationist view on immigration. Through the ten year range, the terminology becomes clearer and the concepts appear more familiar. However, statistics remain a central way of conceptualising immigrants, creating a picture of objectives subordinate to social structures rather than individuals and different groups of people. The approaches turn more multileveled through the temporal range - as the 1999 material talks about 'floods of immigrants' (HS 22.4.1999), in the later periods it is stated that 'asylum seekers are individuals, not 'floods' or 'streams"' (HS 28.2.2004). In some texts from 2009, micro-level aspects of immigration are brought into the structure dominated discussion, introducing everyday life as an aspect of immigration and multiculturalism at the level of experience.

When speaking about integration one should use as a starting point that immigrants are part of the population living in Finland and as different from each other as the rest of the population. (HS -Mielipide, 11.6.2009) (mm).

Yet, immigration continues to be largely constructed in a dichotomist relation to Finnishness, positioning the immigrant as the Other, and the member of the majority population and the Finnish state as the norm and authority. A more inclusive public sphere would require a reassessment of the standard positions, such as the 'model Finn', and a questioning of the essentialising trends within policy making, in favour of a more reflexive approach towards social belonging.

\subsection{Concluding discussion}

In this article, we have briefly examined how various discursive frames pertaining to national unity have been evoked in parliamentary and media discourses revolving around immigration legislation within the past decade. We discovered that the concern with preserving a common national fabric is often expressed in terms of an external threat posed by the immigrant Other, rather than as a function 'internally' dividing developments. While this is interesting enough on its own, this finding should be evaluated in conjunction to the discontinuity between the readily available quantitative data on a relatively low immigrant presence (in the European context) and the sharp increase in accounts that link this presence to various threats for national identity and solidarity. A particularly lucid account of the latter is given by 
the immigration director of the Ministry of Interior who recently reiterated the often ignored fact that the current dimensions of the inflow of immigrants per se cannot result in any demographically relevant changes in Finland in the foreseeable future (HS -Mielipide, 17.8.2009). Again, the perceptions of national unity being threatened by the immigrant Other appear independent from the objectively measurable dimensions of immigration. Therefore, in order to overcome some of the nationally implemented hurdles to immigration and to the integration of immigrants, this subjectively experienced frailty in the symbolic boundaries of national unity should to be taken into account.

One of the most valuable conclusions from our enquiry relates to the possibility for a researcher to discursively overcome some of the untenable and misguided convictions. Whereas measurable demographic facts play only a limited role in alleviating the fear of the Other, many of the discursive practices also contain implicit hints as to how such ethno-nationalistic discourses could possibly be developed into a direction that is more adaptive towards societal change and would better facilitate integration. Making careful use of these hints is called for in order to develop the immigration policy towards a direction more responsive to upcoming developments, without being hindered by the kind of fears for the future of national unity that can be downplayed in a different way to contextualise the necessity for these developments.

Firstly, the instrumentalist mindset that attempts to weigh the pros and cons in opening and revising certain nationally determined practices is at a loss at measuring them ordinally and arguing for some losses to be an acceptable price for certain gains. The statement by the Minister of Interior Kari Rajamäki underlines this difficulty; according to him, reaping benefits must be subject to minimising problems and not the other way around. Therefore, we suggest that in presenting the benefits related to developments that may be regarded as challenging the symbolic boundaries of national unity, special emphasis should be put on scenarios that can be presented as win-win ones, rather than constantly arguing the acceptability of certain losses. While this naturally restricts the scope of benefits one can refer to, this strategy is nevertheless fruitful in the sense that it allows for focussing on instances that will actually be interpreted as beneficial through a mindset fixed on preserving solidarity that is defined in a majoritarian manner. This is particularly important concerning the evidence of the relative impotence of non-binding measures of advisory hearings, through which any, even potentially upsetting suggestions are most commonly channelled.

Secondly, there is a distinct discourse through which any actual or potential structural flaws in the welfare system are discussed in terms of a lack of familiarity and competence of those who suffer from these flaws. In this discourse the Other is defined through the inability to cope with the existing structures. Therefore, it does not appear likely that arguing the existence of structural flaws by underlining the problems they cause to a population outside the nationally defined majority is a prudent way of advancing a more cosmopolitan mindset. It is rather by underlining 
the problems that are caused to both the insiders and outsiders by certain, existing policy structures that more outsiders can be brought within this vaguely defined, symbolic in-group. This is essential in order to facilitate integration on the more concrete level as well.

Thirdly, and similarly to the second point, the ideas challenging the majoritarian paradigm that stresses social cohesion at the national level should not be presented as altogether external to the extant paradigm. This is likely to have repercussions as the republican understanding of national solidarity considers itself threatened by these very ideas. Rather, a more constructive approach would be to argue that many of the positive values linked to developing the existing immigration regime into a more open direction can already be found within the boundaries of the welfare-state ideology and that their implementation would also constitute a more coherent approach to an inclusive and bridging form of solidarity in an increasingly heterogenising society. This strategy would also act against the attempts to pose the 'medicine' as the 'disease' and move the revisionary ideas away from the particular focus on the existing confrontation that is being discursively built between these two ideologies. At the same time it would generate much less of the resentment that currently stems from the fear that it is these cosmopolitan developments that are currently undermining national sovereignty and the state's authority to create public policy.

What is reassuring in the Finnish context is that during the span of twelve years a slight shift in the discourse can be noticed, especially within the media. The fact that metaphors such as 'immigrant floods' have shifted towards an emphasis on the individuality of the immigrants is a start. However, while the media appears to pave the way for an atmosphere suitable for change towards a more cosmopolitan mindset among citizens, it still remains hardly unproblematic in Finland to welcome different cultures and their rights. Moreover, the evidence of current legislative discourse suggests that these are particularly difficult issues to viably promote within the parliamentary context of partisan politics, where no party can afford to dismiss the growing numbers of those critical towards any challenge to a republican and ethnocentrically assimilative nation-state. A change at this parliamentary level can be discursively facilitated by convincingly presenting these particularly critical groups of citizens - and the politicians and media representing them - a convincing picture of the future of national solidarity in an era of increasing societal heterogeneity that does not reaffirm the prejudices and reconstruct the confrontations discussed here. This also entails systematic expert participation in the current debate with facts that challenge existing convictions. 


\section{References}

\section{Empirical Material}

\section{Section 2}

HaVM 4/2004 vp, 2.4.2004 (memorandum of the Administrative parliamentary committee). Interview of Legislative Councellor Jorma Kantola from the Ministry of Interior (5.12.2008). LA 163/2003 vp, 15.12.2003 (motion for an alternative Aliens Act by Esko-Juhani Tennilä (LA)). Ministry of Interior document: Yleinen yhteenveto ulkomaalaislakityöryhmä mietinnöstä annetuista lausunnoista, 26.2.2002 (memorandum containing the general overview of the statements concerning aliens act of 2004).

Ministry of Labour document: dnro 361/832/98TM, 15.9.1999 (application for continued funding for the research project: 'Interview Study on the Employment Prospects of the Immigrants', ordered by the Ministry of Labour).

PTK 40/2003 vp, 16.6 .2003 (minutes of the parliamentary plenary session).

\section{Section 3}

Integration Act (Act on the Integration of Immigrants and Reception of Asylum Seekers)

PTK 195/2002 vp, 5.2.2003 (Follow-up debate on the Government Report on the implementation of the Act [VNS 5/2002 vp]).

\section{Aliens Act}

PTK 40/2003 vp, 16.6 .2003 (preliminary debate on the legislative proposal).

PTK 99/2003 vp, 25.11.2003 (preliminary debate on supplementary government proposal).

PTK 16/2004 vp, 26.2.2004 (preliminary debate on a legislative motion).

PTK 39/2004 vp, 14.4.2004 (first reading: general debate).

PTK 45/2004 vp, 21.4.2004 (first reading: detailed handling).

\section{Section 4}

Helsingin Sanomat online archive of articles

word search 'kotouttamislaki' [Integration Act]

1998-1999: 14 articles

2008-2009: 9 articles

word search 'ulkomaalaislaki' [Alien's Act]

2004: 118 articles

Helsingin Sanomat Internet forum

Discussions on the Integration Act and Aliens Act

$$
\text { 2.6.-15.6.2009: } 217 \text { comments }
$$

\section{Conclusion}

Helsingin Sanomat online archive of articles

Letter to the editor by Mervi Virtanen, the director of the Migration Unit in the Ministry of Interior

(17.8.2009).

\section{Literature}

Bail, C. A. 2008. "The Configuration of Symbolic Boundaries against Immigrants in Europe", American Sociological Review 73(1), 37-59. 
Caponio, T. and M. Borkert, ed. 2010. Local Dimension of Migration Policymaking. Amsterdam: Amsterdam University Press.

Crepaz, M. 2006. ''If you are my brother, I may give you a dime!' Public opinion on multiculturalism, trust and the welfare state." Pp. 92-117 in Multiculturalism and the Welfare State: Recognition and Redistribution in Contemporary Democracies, edited by K. Banting and W. Kymlicka. Oxford: OUP.

Eide, E. 2008. "The Loop of Labeling. Orientalism, Occidentalism and the Cartoon Crisis." in Transnational Media Events. The Mohammed Cartoons and the Imagined Clash of Civilizations, edited by E. Eide, R. Kunelius and A. Philips. Gothenburg: Nordicom.

Esping-Andersen, G. 1990. The Three Worlds of Welfare Capitalism. Cambridge: Polity.

Favell, A. 2001. Philosophies of Integration: Immigration and the Idea of Citizenship in France and Britain. Houndmills: Palgrave.

Hall, S., ed. 1997. Representation : cultural representations and signifying practices. London, SAGE. Hemerijck, A. 2004. "The Self-Transformation of the European Social Model(s)" Pp. 173-213 in Why We Need a New Welfare State, edited by G. Esping-Andersen, D. Gallie, A. Hemerijck and J. Myles. Oxford: OUP.

Horsti, K. 2005. Vierauden rajat: monikulttuurisuus ja turvapaikanhakijat journalismissa. Tampere: Tampere University Press.

Keskinen, S., A. Rastas and S. Tuori, ed. 2009. En ole Rasisti, mutta... Maahanmuutosta, monikulttuurisuudesta ja kritiikistä. Tampere: Vastapaino.

Kymlicka, W. 2000. Multicultural Citizenship. Oxford: Clarendon Press.

Lahav, G. 2004. Immigration and politics in the new Europe: Reinventing Borders. Cambridge: CUP.

Lepola, 0. 2000. Ulkomaalaisesta suomenmaalaiseksi. Monikulttuurisuus, kansalaisuus ja suomalaisuus 1990-luvun maahanmuuttopoliittisessa keskustelussa. Helsinki: Suomalaisen kirjallisuuden seura.

Lijphart, A. 1984. Democracies: Patterns of Majoritarian and Consensus Government in Twenty-One Countries. New Haven: Yale University Press. . 2008. Thinking about Democracy. Power: Sharing and Majority Rule in Theory and Practice. New York: Routledge.

Lukes, S. 1974. Power: A Radical View. Houndmills: Palgrave Macmillan.

Löytty, 0. 2005. "Toiseus. Kuinka tutkia kohtaamisia ja valtaa." Pp. 161-189 in Suomalainen vieraskirja. Kuinka käsitellä monikulttuurisuutta, edited by A. Rastas, L. Huttunen and 0. Löytty. Tampere: Vastapaino.

Mclver, S. 2003. "Contextualising National Identity. Others, Othering and Irishness." Pp. 43-60 in Identity Dynamics and the Construction of Boundaries, edited by B. Petersson and E. Clark. Lund: Nordic Academic Press.

Paasi, A. 2002. "Rajat ja identiteetti globalisoituvassa maailmassa." Pp. 154-176 in Eletty ja muistettu tila, edited by T. Syrjämaa and J. Tunturi. Helsinki: Suomalaisen kirjallisuuden seura.

Pekonen, K. 2008. “Two Versions of Representative Talk in Finnish Parliament.” Pp. 208-229 in The Parliamentary Style of Politics, edited by S. Soininen and T. Turkka. Helsinki: Finnish Political Science Association.

Pietikäinen, S. 2000. Discourses of Differentiation: Ethnic Representations in Newspaper Texts. Jyväskylä: University of Jyväskylä.

Putnam, R. 2000. Bowling Alone. The Collapse and Revival of American Community. New York: Simon \& Schuster.

. 2007. "E Pluribus Unum: Diversity and Community in the Twenty-first Century. The 2006 Johan Skytte Prize Lecture." Scandinavian Political Studies 30(2): 137-174.

Saward, M. 2006. “The Representative Claim." Contemporary Political Theory 5(3): 297-318. 
Schuller, T., S. Baron and J. Field. 2000. "Social Capital: A Review and Critique.” Pp. 1-38 in Social Capital: Critical Perspectives, edited by S. Baron, J. Field and T. Schuller. New York: Oxford University Press.

Simmel, G. 1981. Hur är samhället möjligt? - och andra essäer. Göteborg: Korpen.

Soysal, Y. N. 1994. Limits of citizenship: migrants and postnational membership in Europe. Chicago: The University of Chicago Press.

Taylor, C. and A. Gutmann, ed. 1992. Multiculturalism and "The Politics of Recognition". Princeton: Princeton University Press.

Turja, T. 2008. "Styles of Parliamentary Speech in the Plenary Session of the Parliament of Finland." Pp. 155-183 in The Parliamentary Style of Politics, edited by S. Soininen and T. Turkka. Helsinki: Finnish Political Science Association. 


\section{Appendix 1: Original Quotes}

a) [R]ajat ylittävän muuttoliikkeen lisääntymisen myönteiset puolet oli hyödynnettävä ja samalla oli saatava siihen liittyvät haittavaikutukset niin pieniksi kuin mahdollista. [...] Hallitus on pitänyt tärkeänä, että esitys ulkomaalaislaiksi saatetaan edellä mainituin perustein ja kuten alussa totesin eduskunnan käsiteltäväksi pikaisesti.

b) Uudistuksen perimmäisenä tavoitteena on ollut löytää tasapainoinen kokonaisuus, jossa otetaan huomioon niin Suomen sisäinen turvallisuus kuin maahan tulevien ja maassa oleskelevien ulkomaalaisten oikeudetkin.

c) Joissain yhdistyksissä ollaan oltu tyytymättömiä Ulkomaalaislakiin ja on väitetty, että siinä ei ole huomioitu vähemmistöjen näkemyksiä, mutta se ei pidä paikkaansa. Kaikki esitetyt lausunnot on otettu huomioon valmistelussa. Mutta vähemmistön linjauksia ei ole helppo toteuttaa kun enemmistö on eri mieltä.

d) Lapsen etu on aina yksilöllinen ja sidottu lapsen kulloiseenkin elämäntilanteeseen. Lapsen etu tulee harkita kokonaisuudessaan ottaen huomioon mahdollisuuksien mukaan lapsen toivomukset, mielipiteet ja yksilölliset tarpeet.

e) Mitä tulee siihen, onko Suomi aivan erillinen valtio [...] itse en usko tähän.

f) Tämän eduskunnan keskeinen tehtävä, meidän pitää se muistaa, on huolehtiminen omista kansalaisista. Omista kansalaisistamme huolehtiminen edellyttää tietyissä tilanteissa, että me otamme tänne ja ilman muuta ulkomaalaisia työntekijöitä, pakolaisia, pidämme heistä huolen. Se kuuluu siihen kokonaisuuteen. Mutta kuten sanoin, ykkösasia on se, että me päätämme tässä salissa ennen kaikkea suomalaisten ihmisten ongelmista.

g) Suomella ja suomalaisilla on aina oikeus päättää siitä, keitä tänne tulee ja kuinka paljon. Se on meidän tehtävämme ja meidän oikeutemme tässä maassa, niin kuin turkkilaisilla Turkissa, niin kuin slovakeilla Slovakiassa ja ruotsalaisilla Ruotsissa. Tämä on kansallinen kysymys.

h) eikä se ole Suomen edunkaan mukaista, että me pienen Viron parasta työvoimaa yrittäisimme houkutella tänne, vaan kyllä sen pitää olla siellä hoitamassa isänmaallisia velvoitteita.

i) Suomessa asuu tällä hetkellä noin 100000 ulkomaalaista. Suomella onkin verrattain lyhyt maahanmuuttohistoria. Ehkä siitä johtuen emme osaa vielä kunnolla tunnistaa ja hyödyntää maahanmuuttajien mukanaan tuomaa sosiaalista, kielellistä ja 
kulttuurista osaamista. Tämän olemassa olevan, mutta käyttämättömän voimavaran saaminen hyötykäyttöön palvelisi Suomea monella eri rintamalla.

j) Kunpa joku toisi sen luvun suoraan ja kertoisi sen totuuden, ketkä ovat todellisia pakolaisia ja ketkä ovat tulleet vain paremman uskon toivossa [po. 'paremman elämän toivossa'? MW].

k) Mitä enemmän meillä on perusteettomasti turvapaikkaa hakevia henkilöitä, jotka ovat saapuneet maahamme pelkästään kokeilemaan sosiaaliturvaamme, sitä vähemmän meille jää resursseja ottaa vastaan niitä henkilöitä, jotka tosiasiassa olisivat turvapaikan tarpeessa.

1) On erittäin tärkeää toimia harmaata taloutta vastaan, koska väkisinkin, jos se päästetään kasvamaan,[...] niin se murentaa suomalaista työmoraalia, suomalaista etiikkaa, meidän käyttäytymistämme. Tämä tällainen varsin korkea etiikka, että verot maksetaan ja sakot maksetaan [...] on syntynyt kuitenkin vuosisatojen kuluessa. Aika lyhyesti tällainen moraalietiikka voi myöskin heikentyä, jos sille tilaa annetaan.

m) Vaarana on, että hallitsematon maahanmuutto sotkee työmarkkinat ja työnantajat pääsevät käyttämään hyväkseen ulkomaalaisten hädänalaista asemaa.

n) [J]os me osaamme oikein hoitaa tämän ulkomaalaispolitiikan, se myöskin estää meillä hyvin tehokkaasti rasismin eteenpäintuomista, joka nyt jo kytee [...] monissa paikoissa sillä tavalla piilossa ja ihmisten mielissä, mutta se ei tule esiin. Mehän olemme semmoista kansaa, että jupistaan ja jupistaan ja sitten mennään nurkan taakse ja annetaan muijalle ja lapsille selkään, kun puhutaan, että olisi tehnyt mieli sanoa siellä kokouksessa ja olisi pitänyt sanoa sille porukalle kerrankin kunnon sanat, mutta kun ei kehdata sanoa, mennään nurkan taakse ja tehdään tämmöiset jutut. [...] [K]un tämä rasismi oikein kunnolla pääsee ryöpsähtämään, kuten Joensuussa yhdessä vaiheessa teki, kyllä se johtuu siitä, että sinne yhteen paikkakuntaan pakkautuu liikaa väkeä ja ihmiset kokevat, että he ovat nyt eriarvoisessa asemassa.

o) Kotouttamissuunnitelman tarkoituksena on antaa maahanmuuttajalle tosiasialliset mahdollisuudet oppia oman elämän hallinta ja saavuttaa taito ja kyky hankkia toimeentulo Suomessa.

p) Tuntuu vain, että erillisille viranomaisille, ministeriöille ja eri organisaatioille maahanmuuttajat ovat vain pakollisia olemassaolon objekteja, joita heidän täytyy ohjata taikka neuvoa, tehdä näitä suunnitelmia.

q) kansalais- ja maahanmuuttajärjestöille on annettava halutessaan mahdollisuus osallistua kunnan kotouttamisohjelman valmisteluun ja täytäntöönpanoon. 
r) Työpaikka on aikuiselle pakolaiselle lähes ainoa tie päästä mukaan suomalaiseen elämänmenoon ja sopeutua uuteen kotimaahansa. [...] opittaessa maan tavalle.

s) Odotusaikana maahanmuuttajat eivät välttämättä saa mitään tietoa suomalaisesta yhteiskunnasta. [...] 'Ihmiset kyllä lähtökohtaisesti haluavat kotoutua'.

t) Kotoutuminen on kansantaloudellisesti tärkeää, sillä työttömät maahanmuuttajat aiheuttavat yhteiskunnalle vain kuluja eivätkä maksa veroja.

u) [...] 20-vuotias nuori tuo Suomen kansantalouteen 850000 markkaa, koulutettu insinööri, lääkäri tai sairaanhoitaja noin 2,5 miljoonaa markkaa.

v) Työvoiman kokonaistarve on Etelä-Savon TE-keskuksen mukaan kaakkoisessa Suomessa vuoteen 2015 mennessä 75000 henkeä poistuman ja uusien tarpeiden korvaamiseksi.

w) Maahanmuuttajissa on niitä, jotka todella haluaisivat tehdä ammattiaan vastaavaa työtä ja joille työnhaku voisi lainsäädännöllisten muutosten avulla tulla helpommaksi [...]. Eli menetämme monia hyviä veronmaksajia.

x) Maahanmuuttajakoulutukseen käytetään vuodessa noin 30 miljoonaa euroa.

y) Kunnilla on aikaa syyskuun loppuun tehdä suunnitelma jokaiselle, joka ei omin avuin saa työtä. [...] Rahaa kunnille ei annettu

z) pakolaisilla taitaa harvemmin olla työkokemusta, jota täällä voisi soveltaa

aa) [...] pakolaisille turvataan tilapäinen oleskelu ja heidän paluunsa kotiin turvataan. Heistä ei tule kunnan asukkaita

bb) Lapsille järjestetään kouluopetusta äidinkielellä. 'Lapset omaksuvat nopeasti vieraan kielen, ja se voi hankaloittaa heidän paluutaan kotimaahan’ [...]. Aikuisille suomalaista yhteiskuntaa opetetaan juuri sen verran, että he tulevat täällä tilapäisesti toimeen.

cc) Mikä maa ottaa meidät suomalaiset korkeastikoulutetut huippuosaavat työttömät elätettäväkseen?

dd) Milloinkohan syntyisi aloite ja virasto siihen, että suomalaisille nuorille Suomessa tarjottaisiin koulutusta vastaavaa työtä?

ee) Euroopan maahanmuuttajalähiöiden ongelmat halutaan estää Suomessa. 
ff) 1980-luvulla Suomessa oli kauhean vähän ulkomaalaisia. Tulijat olivat pieniä ryhmiä, eikä heistä koettu olevan sosioekonomista uhkaa. Laman aikaan tuli pelkoja, että heitä tulee niin hirveän paljon [...].

gg) Meidän tapamme ei ehkä ole ainoa oikea, mutta se on se, jota enemmistö suomalaisista haluaa maassa harjoittavan.

hh) Valtio voi tietyin edellytyksin päättää siitä, ketkä sen alueelle saavat asettua.

ii) Tilannetta ei ole helppo korjata, kun suomalaistenkin työttömyys on korkea, mutta lain mukaan pitää valita pätevin hakija.

ji) Ymmärrän siis oikein hyvin, jos työnantaja on haluton palkkaamaan maahanmuuttajaa. Niin kauan kuin elämme markkinataloudessa, monelle yritykselle maahanmuuttaja on yksinkertaisesti suurempi riski kuin mahdollisuus.

kk) [...] muuttajalle laaditaan koulutusohjelmia. Ellei muuttaja halua osallistua niihin, hänen toimeentulotukensa pienenee asteittain

11) [...] kotouttamislaki vaatiikin viisaasti saattamaan pakolaiset entistä monipuolisempaan vuorovaikutukseen suomalaisen yhteiskunnan kanssa. [...] Tulija sitoutuu vastikkeeksi saamastaan tuesta opiskelemaan maan kielen, täydentämään ammattitaitoaan ja hankkimaan muut Suomessa tarpeelliset tiedot pystyäkseen elättämään itsensä ja osallistumaan muuhun elämään

$\mathrm{mm})$ Lähtökohdaksi on kotoutumisessa oivallettava, että maahanmuuttajat ovat osa Suomessa asuvaa väestöä ja samalla lailla keskenään erilaisia kuin muukin väestö. 